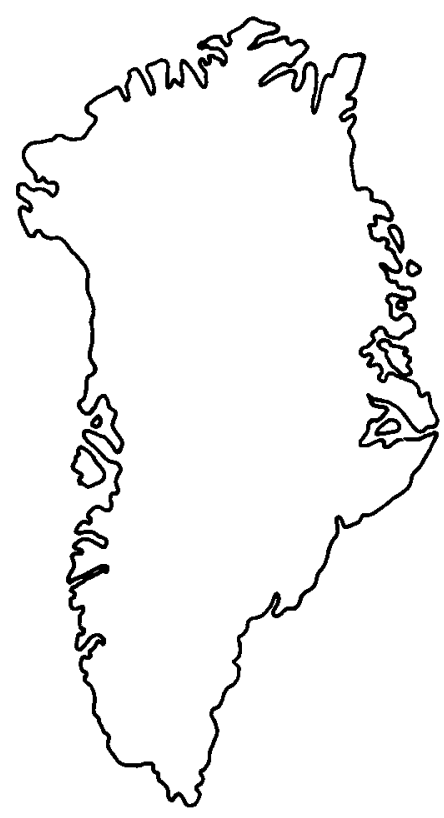

\title{
Sinistral transpression and hydrothermal activity during emplacement of the Early Proterozoic Julianehåb batholith, Ketilidian orogenic belt, South Greenland
}

\author{
Brian Chadwick, Peter Erfurt, Tom Frisch, \\ Ronald A. Frith, Adam A. Garde, \\ Hans Kristian Schфnwandt, Henrik Stendal and \\ Bjørn Thomassen
}

\begin{abstract}
The first systematic investigations of the central part of the Early Proterozoic Ketilidian orogen in the vicinity of Søndre Sermilik in the early 1960s suggested that this part of the orogen comprised a mixture of the Julianehåb granite, altered supracrustal rocks and older orthogneisses. Recent field work has shown that the area consists only of a variably deformed suite of granitic to dioritic plutonic rocks and a range of hornblende-bearing dykes of the appinite suite which all belong to the Julianehăb batholith. Steep to vertical shear zones with widths from a few centimetres to more than one kilometre are a significant element of the structure. The principal shear zones trend north-east and they are parallel to the schistosity and subhorizontal linear structures in the granitoid rocks. Kinematic indicators in many of the shear zones indicate sinistral transcurrent displacements. The relationships between granite fabrics, shear zones and mafic dykes suggest that the Julianehåb batholith was emplaced during subduction from the south towards the Archaean craton in the north-west in a sinistral transpressional system.

Effects of hydrothermal alteration, mainly in the form of quartz veining, silicification, chloritisation, epidotisation and pyritisation, are common within and adjacent to the largest shear zones. These effects are believed to be related to late stages of the evolution of the batholith. Gold anomalies appear to be closely tied to the hydrothermal phenomena.
\end{abstract}

B. C., Earth Resources Centre, University of Exeter, North Park Road, Exeter EX4 $4 Q E$, U.K.

P. E., A. A. G., H. K. S. \& B. T., Geological Survey of Greenland, $\emptyset_{\text {ster Voldgade } 10,}$ $D K-1350$ Copenhagen $K$, Denmark.

T. F. \& R. A. F., Geological Survey of Canada, 601 Booth Street, Ottawa K1A OE8, Canada.

H. S., Geological Institute, University of Copenhagen, Øster Voldgade 10, DK-1350 Copenhagen K, Denmark.

This report describes the results of field work in the area adjacent to Søndre Sermilik, a major fjord north of Nanortalik in South Greenland (Figs 1 and 2). The field work, undertaken in 1993, was the second field season of the project SuPRASYD (Dawes \& Schønwandt, 1992; Nielsen et al., 1993; Garde \& Schønwandt, 1994) which is aimed at a reassessment of the geology of the Early Proterozoic Ketilidian orogen of South Greenland, especially the economic mineral potential of the supracrustal rocks. The field work in 1993 was concentrated in the area north-west of Søndre Sermilik which is dominated by the southern portion of the Early Proterozoic Julianehåb batholith. We use the term 'Julianehåb batholith' in place of the terms 'Julianehåb granite' and 'Granite Zone' used by previous workers (see Allaart, 1976) because of its size, geotectonic setting and wide variation in composition. Our usage is broadly in accord with that of Windley (1991) who described the batholith as "An 80$100 \mathrm{~km}$ wide zone ... which varies from tonalite to granite", although its structural setting appears to be different from that proposed by Windley (see below). In this account we use the terms granite, granodiorite and diorite as 


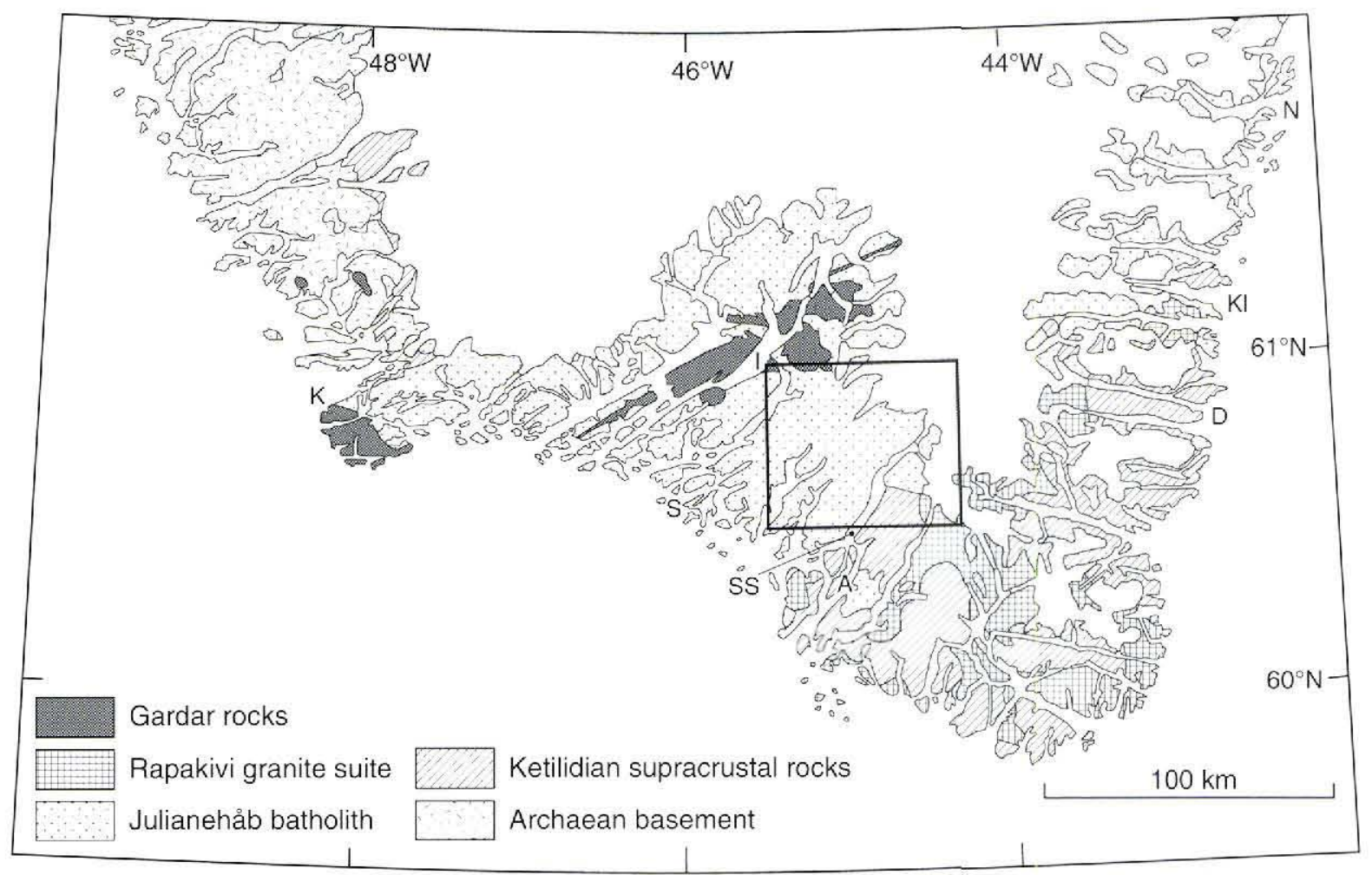

Fig. 1. Geological sketch map of South Greenland with the position of the area discussed in this account (Fig. 2). A: Amitsoq, D: Danell Fjord, I: Igaliko Fjord, K: Kobberminebugt, KI: Kangerluluk, N: Napasorsuaq Fjord, S: Saarloq, SS: Søndre Sermilik.

field terms, based only on outcrop characteristics. The area south-east of Søndre Sermilik is dominated by supracrustal rocks and rapakivi granites of the Ketilidian belt, but none were examined in detail apart from some of the supracrustal rocks in coastal outcrops on the fjord itself.

\section{Previous work}

The results of systematic mapping by GGU during the 1950 s and early 1960s in the Ketilidian orogen (1950$1750 \mathrm{Ma})$ and the Gardar alkaline province (1300-1120 Ma) in the extreme south-west of Greenland were compiled in several published 1:100000 geological map sheets (see Kalsbeek et al., 1990, fig. 1). However, the 1:100 000 map sheet 60 V.3 N, which includes a large area north-west of Søndre Sermilik, was not published, although a substantial part was mapped in 1961-63 (Ayrton \& Weidmann, 1963; Berrangé, 1966; Buttet, 1963; Muller, 1961; Persoz, 1969; Windley, 1966a, b). Our survey in 1993 was largely restricted to the area of this unpublished map sheet.

The results of the surveys of the Ketilidian belt in the 1950s, 1960s and later years were reviewed by Allaart
(1976) and Kalsbeek et al. (1990), the latter as the descriptive text to the 1:500 000 map sheet of South Greenland (Allaart, 1975). These reviews showed not only that the Ketilidian chronological terminology used by early workers was unsatisfactory, but also that their interpretation of much of the Julianehåb batholith and associated mafic igneous rocks in terms of granitisation of supracrustal rocks or pre-existing basement was untenable. The legend of the 1:500 000 map sheet retains elements of the granitisation theory, and parts of the map itself are erroneous, for example, with reference to certain amphibolites which were presumed to be granitised basaltic rocks. Only very limited data from the Ketilidian outcrop on the east coast were available for the compilation of the 1:500 000 map sheet (Allaart, 1975; Kalsbeek et al., 1990); the data were drawn from coastal reconnaissance surveys by Andrews et al. (1971, 1973), Bridgwater \& Gormsen (1969) and Bridgwater et al. (1966). One of the principal objectives of the project SUPRASYD is to survey the Ketilidian belt on the east coast, especially the supracrustal rocks, in much greater detail than has been possible hitherto.

Isotopic age data from the Ketilidian belt which became available after the account by Allaart (1976) were 
reviewed by Kalsbeek et al. (1990). The data suggest that accretion of Ketilidian crust took place in the period 1850-1750 Ma, and isotopic compositions indicate that the Ketilidian granites on the west coast are predominantly I-type with insignificant traces of older sialic crust. Isotopic age data of van Breemen et al. (1974) from the batholith are of particular interest in terms of our recent findings. Van Breemen et al. analysed both a 'gneissic granite' from Akuliaruseq (Fig. 2) in the central part of the batholith, and 'late granites' from Qaqortoq/ Julianehåb and between Søndre Sermilik and Tasermiut (Fig. 2). The zircon U-Pb data (supported by less precise $\mathrm{Rb}-\mathrm{Sr}$ whole-rock data) published by van Breemen $e t \mathrm{al}$. (1974) indicate a gap of about $70 \mathrm{Ma}$ between the em- placement of the 'gneissic granite' at $1805 \pm 25 \mathrm{Ma}$ and the 'late granites' at $1740 \pm 20 \mathrm{Ma}$ (we quote recalculations by Kalsbeek et al., 1990 of the original data using updated decay constants). The significance of this apparent age difference is open to question on the grounds of our findings that 'gneissic granites' in the principal sinistral shear zone systems were derived by deformation of granitoid rocks that have been correlated with the Julianehåb granite by previous workers. Further age determinations are required to determine if the batholith was generated in two distinct stages or emplaced more or less continually over a period in the order of $70 \mathrm{Ma}$.

Windley (1991) used the isotopic age data and the results of previous surveys within the Ketilidian belt to

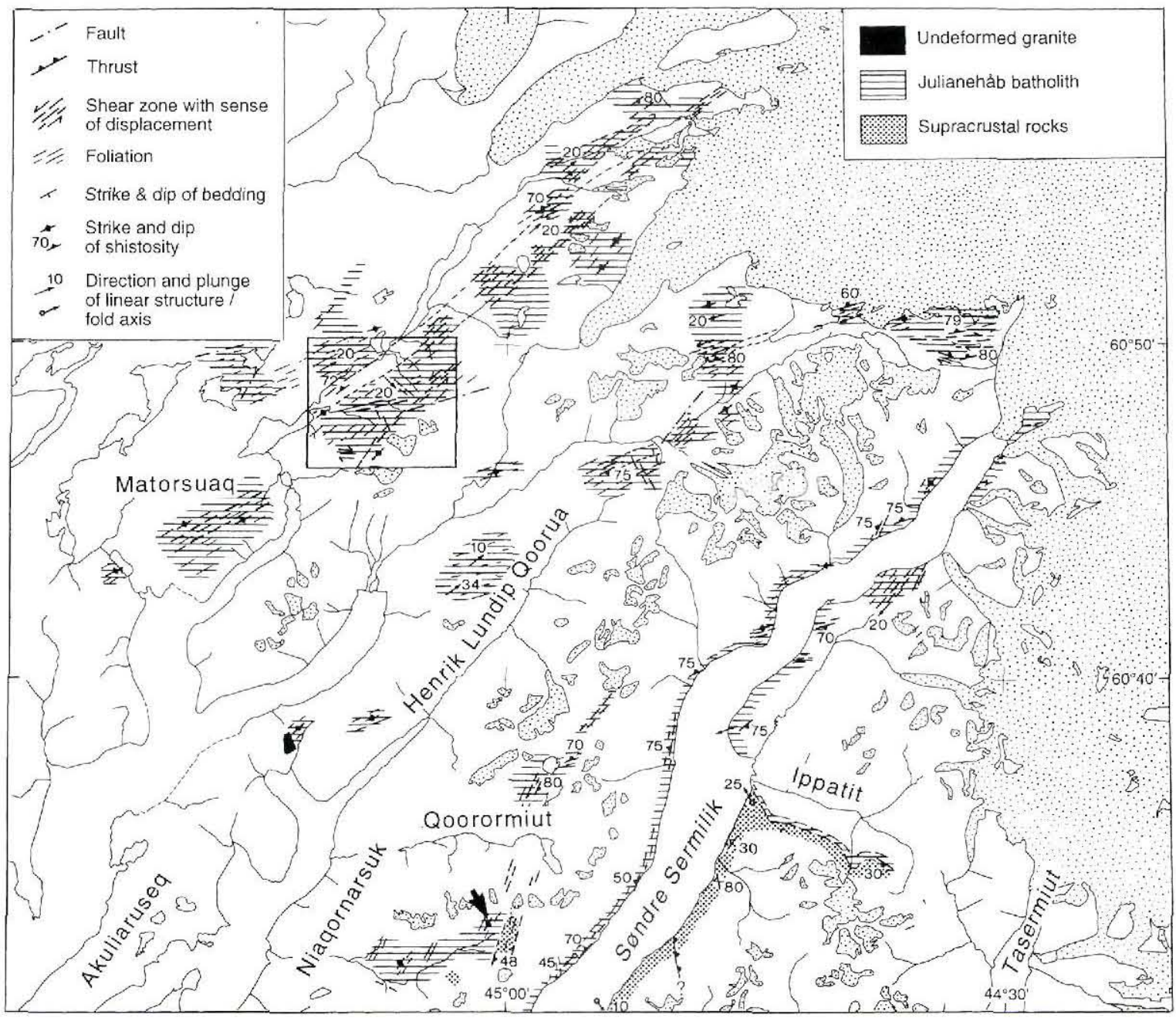

Fig. 2. Part of the Julianehåb batholith and major shear zone systems mapped within the Søndre Sermilik area $(1: 100) 000$ map sheet area Søndre Sermilik 60 V.3 N; see Fig. 1 for location). Almost the entire area consists of granitoid rocks, but only areas studied on the ground in 1993 are marked. The batholith contains several major NE-trending shear zone systems, most of which are located along or in the vicinity of the largest fjords. The framed area is shown in greater detail on Fig. 7. The arrow shows the location of Fig. 9. 
suggest a plate tectonic model similar to that proposed for the Himalayas. Our observations in the area of Søndre Sermilik have several implications for the model proposed by Windley, which are discussed below.

Exploration for economic mineral deposits in the area has concentrated on graphite, uranium, copper, nickel, platinum and gold. Surveys in the early part of this century led to the opening of a graphite mine in pelitic schists on Amitsoq island (Fig. 1) which lies south-west of Søndre Sermilik. The mine produced 6000 tons of graphite before it closed in 1922 (Ball, 1923; Bondam, 1992). Small intrusions of hornblende peridotite (Berrangé, 1970; Schönwandt, 1972; Karup-Møller, 1974) were examined for copper, nickel and platinum, but none were of commercial interest (Turner et al., 1988). Regional geochemical and geophysical surveys by GGU in the period 1979-1984 demonstrated that the Ketilidian belt and the younger Gardar terrain together include an important uranium province (Armour-Brown et al., 1982, 1983; Armour-Brown, 1986; Steenfelt \& Armour-Brown, 1988). Gold was first detected in the Ketilidian belt in 1986 by panning stream sediments (Nielsen, 1987) and a regional distribution of gold was subsequently proved by stream sediment analysis (Steenfelt, 1987, 1990; Steenfelt \& Tukainen, 1991). These findings led to detailed exploration by mining companies (Appel et al., 1993), and chip sampling by Nuna Oil A/S disclosed local gold mineralisation in the parts per million range in the Søndre Sermilik area (J. L. Pedersen, personal communication, 1994). A significant auriferous quartz vein with visible gold hosted by metabasalts was located in the Ketilidian supracrustal rocks south of Søndre Sermilik. The vein has yielded an average of $51 \mathrm{ppm}$ Au over a width of $0.46 \mathrm{~m}$ (Gowen et al., 1993).

\section{Supracrustal rocks adjacent to Søndre Sermilik}

The Ketilidian supracrustal rocks that are exposed on the coast and high ground adjacent to Søndre Sermilik lie on the north-western margin of a regional zone of psammites, pelites and metavolcanic rocks which extends southwards towards the southern tip of Greenland (Escher, 1966; Dawes, 1970). High temperature - low pressure amphibolite and granulite facies metamorphism during Ketilidian deformation and emplacement of rapakivi granites gave rise to widespread migmatisation within the zone of supracrustal rocks.

East of Søndre Sermilik the supracrustal rocks occur within a large syncline with an overturned north-east limb dipping steeply north-east. The south-west limb is shallow or flat-lying. Coastal outcrops on the south-eastern shore of Søndre Sermilik display recumbent isoclines with amplitudes tens of metres in size in semipelites and pelites. Similar pelites on the opposite coast of the fjord trend NE-SW and dip steeply north-west. Their relationship with the isoclinally folded pelites on the south coast is unknown. The supracrustal rocks overlie foliated granitoid rocks of the Julianehåb batholith in the mountains south-east of Søndre Sermilik. The contact as seen on steep mountain faces in the valley Ippatit is sharp and parallel to an intense foliation in both groups of rocks, but extensive networks of white aplitic or pegmatitic sheets occur locally along parts of the contact. Nielsen et al. (1993) reported that the contact is intrusive, but our observations suggest that it may be a thrust.

Strongly foliated, partly migmatised semipelites immediately overlie the granitoid rocks of the Julianehåb batholith. They are overlain by approximately $500 \mathrm{~m}$ of foliated amphibolites. Boulders of deformed pillow-structured amphibolite found in talus indicate that much of the amphibolite is metavolcanic. A small intercalation of amphibolite with abundant leucocratic and mafic inclusions occurs in the foliated amphibolites in the overturned limb of the major syncline in the mountains south of Søndre Sermilik. The inclusions are matrix-supported and unsorted. They have rounded ellipsoidal shapes which are the result of deformation and they range from a few centimetres to $1 \mathrm{~m}$ in length. A thin section of a leucocratic inclusion shows that it is dominated by plagioclase and hornblende with minor quartz and accessory titanite and an opaque mineral. The amphibolite matrix comprises hornblende and plagioclase with subordinate quartz and biotite. More detailed mapping is required to establish whether the intercalation is volcanoclastic or intrusive.

The metavolcanic rocks are locally overlain by finely laminated, black pelites. These pelites are overlain by pale to dark grey psammites with a minimum thickness of c. $1000 \mathrm{~m}$. The psammites in the shallow limb of the syncline are heavily migmatised, but those in the steep overturned limb are less migmatised and preserve numerous primary depositional structures. Coarse polymict conglomerates are relatively common within the psammites. Some are a few metres thick, but most of the conglomerates occur as relatively thin basal layers to graded psammite beds up to $1 \mathrm{~m}$ thick. The thick beds of conglomerate include closely packed clasts which range from boulders of granodiorite up to $1 \mathrm{~m}$ long to smaller clasts of dark and pale, presumed metavolcanic rocks, vein quartz, metadolerite and a variety of granitoid compositions including aplite. Conglomerates forming the basal parts of graded beds of psammite are matrix-supported. The clasts are $5-20 \mathrm{~cm}$ in size, well rounded and predominantly of granitoid rocks with subordinate clasts of semipelite which may include abundant detrital mag- 
Fig. 3. Cross-bedded psammites south-east of Sundre Sermilik. Subhorizontal exposure of steeply inclined, SE-striking rocks, truncated foreset beds indicate right way up to the south-west.

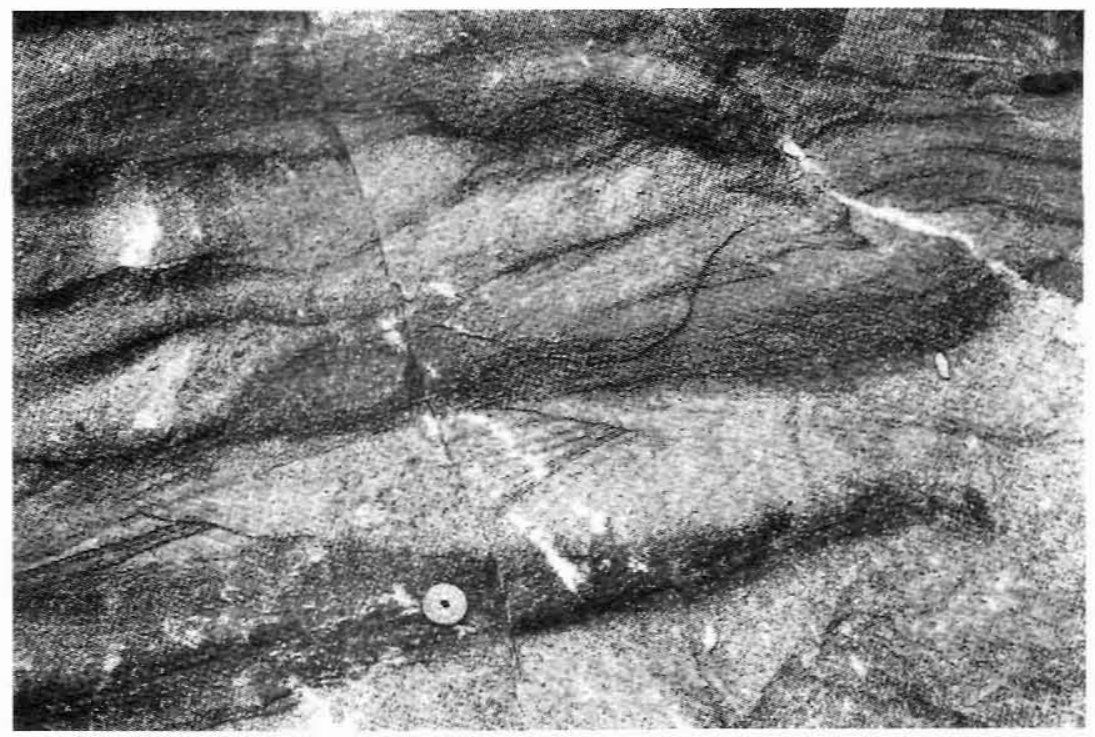

netite. The conglomerates are variably deformed, and the clasts commonly have elongate ellipsoidal shapes.

The psammites have bedding thicknesses in the order of $1-2 \mathrm{~m}$ and coarse trough cross-bedding is relatively common (Fig. 3). Detrital magnetite, titanite and apatite are concentrated on some foreset beds. The psammites consist largely of quartz, plagioclase and microcline with accessory biotite, muscovite and chlorite. The shapes of most of the original detrital grains have been strongly modified by metamorphic recrystallisation. The trough cross-bedding and the well-rounded clasts suggest that the psammites were deposited in a high energy fluvial system or marine deltaic environment.

\section{The Julianehåb batholith}

We use the term 'Julianehåb batholith' to describe the large outcrop of granites, granodiorites, diorites and subordinate amphibolite dykes and metagabbros which extends from Kobberminebugt to Søndre Sermilik in the south-west of South Greenland and from Napasorsuaq Fjord to Kangerluluk on the south-east coast. The total
Fig 4. Granite with swarms of thin, in part deformed, amphibolite dykes. The cliff face is about $100 \mathrm{~m}$ high.

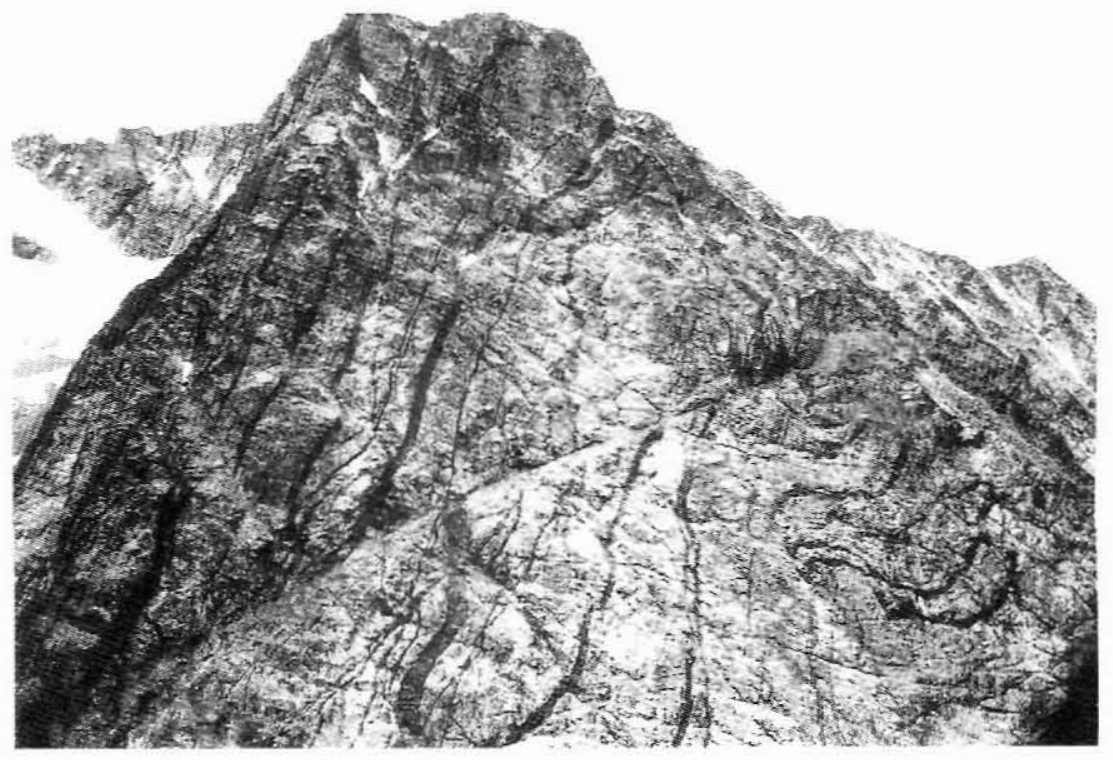



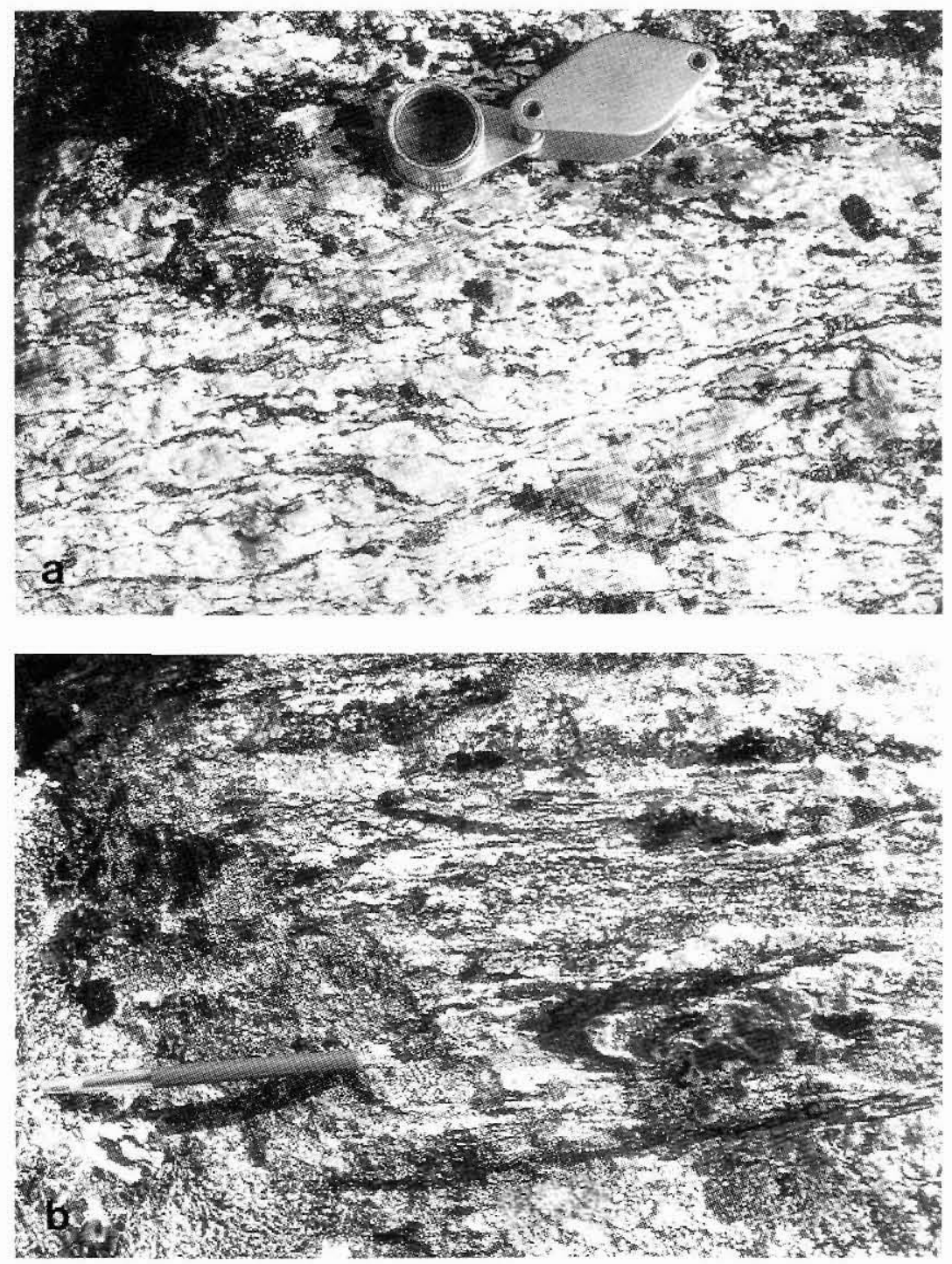

Fig. 5. Small-scale structures and fabrics in the Julianehăb granites, illustrating different stages of deformation during granite emplacement and sinistral transpression. (a) Sinistral SC fabric and sigmoidal feldspar porphyroclasts in moderately deformed porphyritic granite (horizontal surface; $\mathrm{C}$ planes strike $c .50^{\circ}$ ). (b) L tectonite with subhorizontal stretching lineation and rootless isoclinal folds (plunge $10^{\circ}$ to $076^{\circ}$ ). (c) Strongly foliated granite (strike $50^{\circ}$ ) with a $10 \mathrm{~cm}$ thick conjugate dextral shear zone trending $96^{\circ}$. Note the fold and adjacent pressure shadow (right of the pen), and normal slip crenulation of the shear zone indicating dextral movement. Further information about the orientations of conjugate sinistral and dextral shear zones is shown on Fig. 7. (d) Centimetre-thick layers of mylonite and ultramylonite separated by thin layers of intensely foliated granite in a shear zone. area of the batholith, including that part beneath the Inland Ice, is in the order of $30000 \mathrm{~km}^{2}$. The batholith formed by polyphase syntectonic and late kinematic emplacement of a range of acid and intermediate plutonic rocks with subordinate swarms of amphibolite dykes (Fig. 4). Detailed descriptions of parts of the batholith have been reviewed by Allaart (1976). Systematic stream sediment geochemical surveys covering the whole of South Greenland indicate that the north-western part of the batholith is generally the most leucocratic, and porphyritic granites with low strain are more common here than elsewhere (A. Steenfelt, personal communication, 1994). Bridgwater et al. (1973) drew attention to the similarities of the Julianehăb granite batholith with the Andean batholiths. They pointed out that xenoliths in the Julianehăb batholith had $\mathrm{a}$ general horizontal elongation which was consistent with transcurrent displacements suggested by fabrics in the Kobberminebugt belt on its northern boundary (Watterson, 1965, 1968) and steep shear zones in the Saarloq (Sardloq) area (mapped by Windley, 1966a, b) and on the Akuliaruseq peninsula (mapped by Persoz, 1969) in the south.

The batholith north-west of Søndre Sermilik consists of a complex range of porphyritic granites, granodiorites and hornblende diorites with major swarms of amphibolite dykes in which grey granodiorite predominates. Most of the plutonic rocks have steeply dipping or vertical S fabrics (variably penetrative schistosity) trending NE-SW (Fig. 5a). Scattered inclusions of green hornblende diorite which range from a few centimetres to 50 $\mathrm{cm}$ in size are common in some outcrops of granodiorite (Fig. 6a-b). Many of the inclusions include porphyritic plagioclase and some contain coarse hornblende. Other inclusions are uniform. coarse-grained hornblende dio- 
rite. Net-veined dykes of diorite and concentrations of dioritic inclusions in cross-cutting sheets suggest that the scattered small inclusions formed by the disruption of immiscible injections of hornblende diorite were contemporaneous with their host granodiorite. The rounded shape and the distribution of the inclusions may suggest that they were injected in the form of a stream of globules; alternatively the inclusions may represent trapped fragments of consanguineous diorite intrusions, as suggested by the relationship shown on Fig. 6c. The original shapes of the diorite inclusions have been modified by deformation to prolate ellipsoids with their long axes plunging gently NE parallel to linear fabrics in the plane of the $\mathrm{S}$ fabric in the host granodiorite (Fig. 6). In many outcrops of granodiorite the linear fabric predominates and the rock is an L tectonite (Fig. 5b).
One of the objectives of the field work was to examine the large bodies of basic rocks which are shown on the 1:500 000 map sheet (Sydgrønland; Allaart, 1975) as being of unknown origin. One of the largest of these bodies occurs in the area north-west of Søndre Sermilik and was mapped by Persoz (1969) as an amphibolite. He interpreted the body in terms of the granitisation theory that was current in the 1960s, and suggested that much of the finer grained amphibolite may have been volcanic. whereas the coarser part may have been gabbroic. Consequently, he believed that the large bodies of mafic rocks were older than their host granodiorite. We found that the mafic bodies are hornblende diorites with variable degrees of net-veining. They are identical in composition to the small inclusions of diorite which are abundant in many outcrops of the grey granodiorite. The large mafic

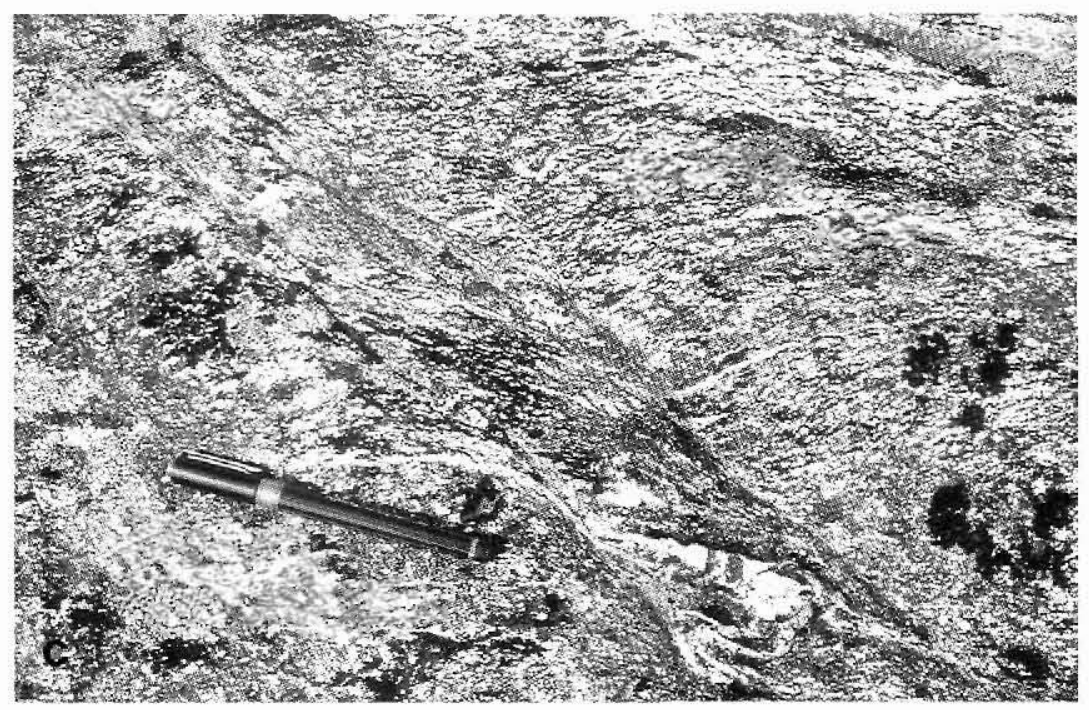

Fig. 5 cont.

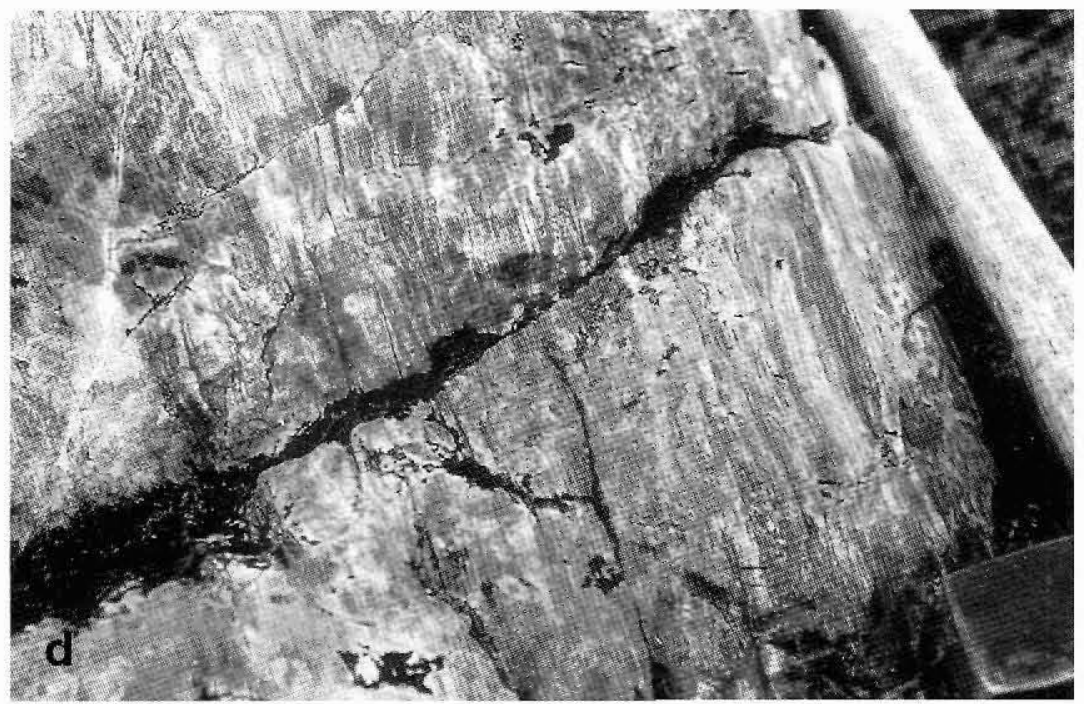




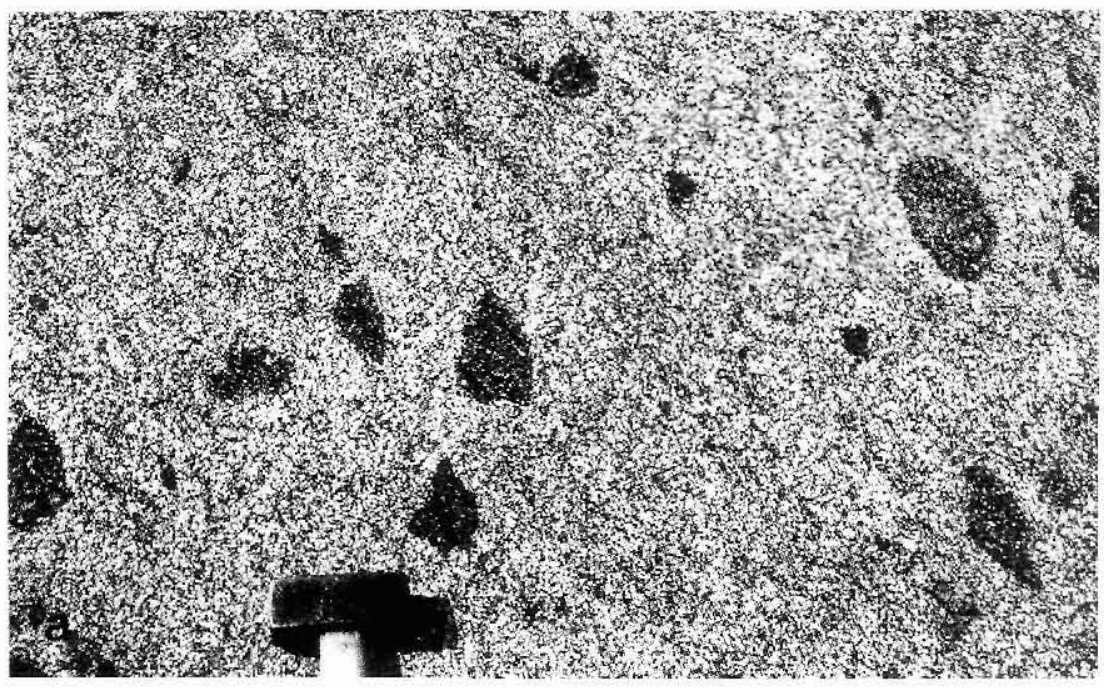

Fig. 6 (a) and (b). Y-Z and $\mathrm{X}-\mathrm{Z}$ planes, respectively, of deformed dioritic inclusions in the Julianehåb granite.

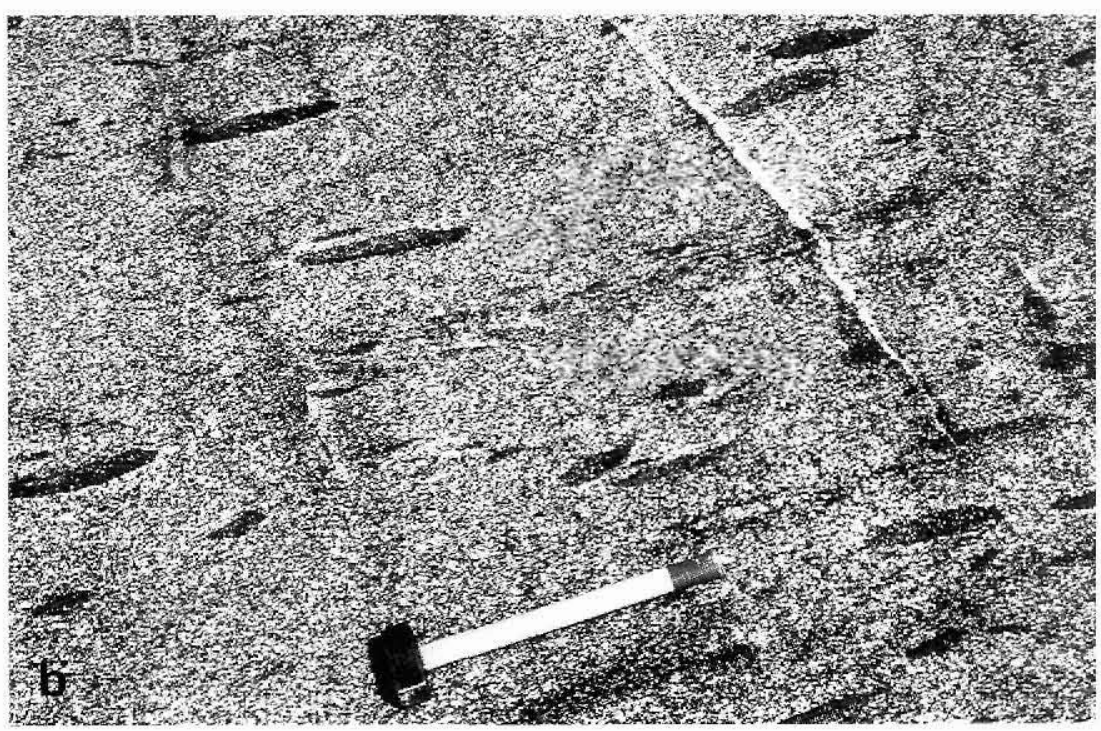

bodies can thus be regarded as contemporaneous with the granite and possibly immiscible phases.

Whereas the bulk of the batholith between Igaliko Fjord and Søndre Sermilik is characterised by penetrative linear and planar fabrics, there are a few major bodies of younger, undeformed, porphyritic granites, for example, that mapped by Persoz (1969) on Akuliaruseq (see Fig. 2).

\section{Structure}

Most of the granodiorites and granites of the Julianehåb batholith visited by us north-west of Søndre Sermilik are characterised by steeply dipping or vertical schistosity trending NE-SW and coaxial mineral and shape fabrics plunging gently $\mathrm{NE}$ in the plane of the schistosity (see Fig. 5). Steep or vertical shear zones broadly coplanar with the schistosity in the granodiorites are significant elements of the regional structure. Many of the shear zones are only a few centimetres wide, but some are several metres wide. The largest shear zone occurs in the north-western part of the area visited in 1993. The zone is approximately $1.5 \mathrm{~km}$ wide, can be traced for at least 50 $\mathrm{km}$ along strike and appears to link with intensely deformed rocks in the Saarloq (Sârdloq) area mapped by Windley (1966a, b). He reported only Gardar mylonites in this area. Bridgwater et al. (1973) subsequently interpreted the tract of high strain and complex folding in the Saarloq area as a steep ENE-trending Ketilidian shear zone. Based on descriptions by Bridgwater et al. (1973), Windley (1991) defined the Sârdloq shear zone as a "... 20-30 km-wide high deformation zone (separating) to- 


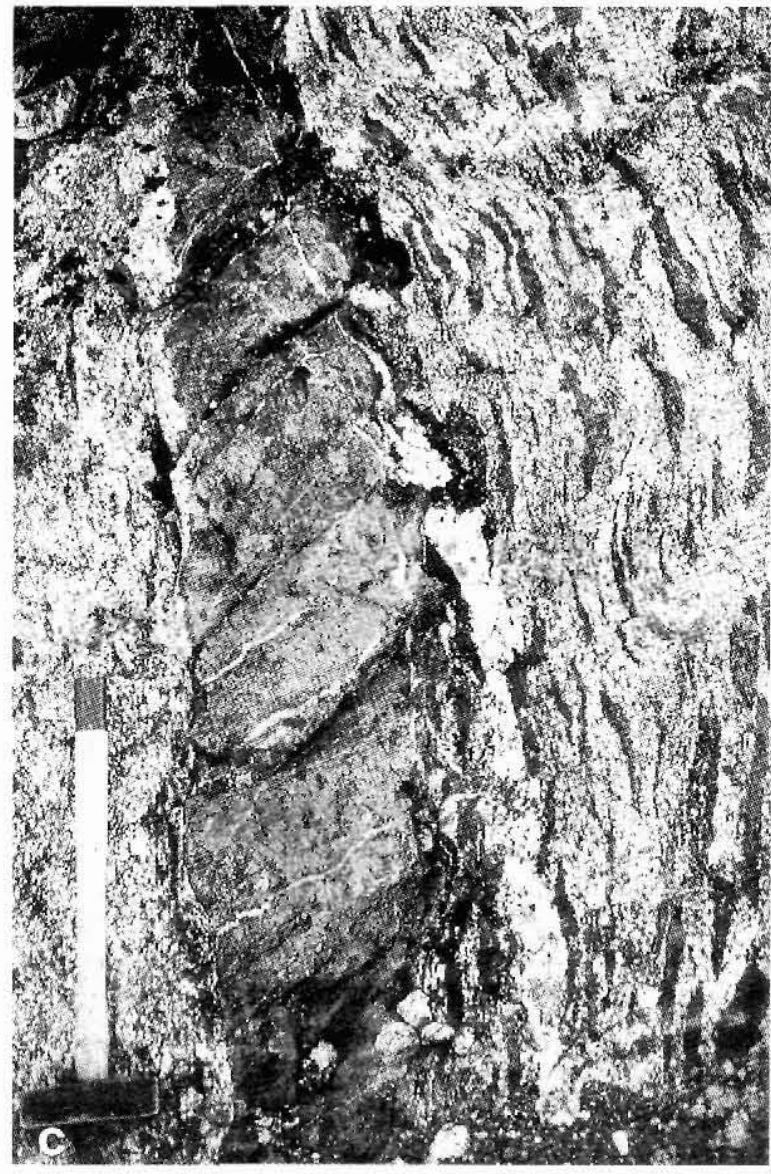

Fig. 6 (c). Dioritic dyke hosted by granite and injected by thin granitoid veins in several directions. Numerous inclusions in the granite adjacent to the right margin of the dyke appear to have been derived from the dyke by a combination of granite injection and contemporaneous ductile deformation. A younger quartz vein is almost parallel to the dyke.

tally different geological terranes - an igneous batholith to the north from a thrust stack of ... supracrustal rocks ... and rapakivi granites to the south. The borders of the zone consist of two 10-15 km-wide steep shear belts ...". Surveys north-west of Søndre Sermilik have now made this definition untenable. There are no shear belts as wide as $10-15 \mathrm{~km}$, and the Sârdloq shear zone does not separate two different terranes but is the largest of several similar shear zones in the midst of the batholith. In addition, the $20-30 \mathrm{~km}$ wide southern part of the batholith is not a zone of uniformly high deformation. We propose that the term Sârdloq shear zone be applied only to the $1.5 \mathrm{~km}$ wide steep belt of mylonites and ultramylonites that we have mapped in the granodiorites north-west of Søndre Sermilik and their probable extension along strike to the SW into the narrow belt of 'veined gneisses' trending NE through Saarloq itself (Windley, 1966a, Map 1).

Mylonites and ultramylonites in the Sârdloq shear zone as we have defined it in the foregoing, and in the other prominent shear zones in the batholith, were derived by intense deformation of the adjacent granodiorites (Figs 5 and 7). S-C fabrics in the shear zone are steeply dipping or vertical. The term $\mathrm{S}-\mathrm{C}$ fabric is used here in the sense of the type I of Lister \& Snoke (1984), i.e. S surfaces are statistically penetrative foliations, whereas $\mathrm{C}$ surfaces are spaced narrow zones of intense shear strain or displacement discontinuities. The regional schistosity in the granodiorites is intensified within $c .100 \mathrm{~m}$ of the shear zone. Within the shear zone the schistosity is intensified further in the $\mathrm{C}$ fabric. The pre-existing $\mathrm{S}$ fabric appears to have been obliterated completely in the ultramylonites (Fig. $5 \mathrm{~d})$. This relationship where a schistosity developed before localised yielding gave rise to shear zones and development of a C fabric has been described by Lister \& Snoke (1984), among others, in terms of plastic yielding and concentration of strain in narrow zones of shearing at a relatively late stage in the regional deformation of granitic and orthogneiss terrains.

Mineral lineations with a shallow NE plunge in the C fabric in the Sârdloq and related shear zones (Fig. 7c) indicate a transcurrent displacement. Lateral displacement of dykes and inclusions, textures of feldspar porphyroclasts, an extensional crenulation fabric (shear bands in the general sense of White et al., 1980; normal slip crenulation in the specific sense of Dennis \& Secor, 1987) and rare asymmetric $S$ folds indicate a consistent sinistral sense of shear. The amount of the displacement in the shear zones is unknown, but in the Sârdloq shear zone alone it was probably many kilometres on the grounds of the width of the zone and the intensity of the mylonitisation. Other small-scale, vertical or steeply dipping, transcurrent sinistral and dextral shear zones trending approximately $\mathrm{N}-\mathrm{S}$ and ESE-WNW appear to have been contemporaneous effects related to the major NEtrending shear zones. The presence of hornblende and biotite as integral parts of the S-C fabrics suggests that the shear zones formed during amphibolite or upper greenschist facies conditions.

Another variety of shear zone trends NE-SW through the mountain Matorsuaq, $1010 \mathrm{~m}$. It is represented by a steeply dipping or vertical belt of high-strain orthogneisses c. $500 \mathrm{~m}$ wide which can be traced aiong strike for at least $10 \mathrm{~km}$. The regional grey granodionte, in places with large inclusions of dark grey titanite-bearing diorite, can be traced into the belt of high-strain gneisses across a transition zone about $25 \mathrm{~m}$ wide. Thin concordant seams and intrafolial ptygmatically folded veins of aplite and pegmatite which are restricted to the shear zone 

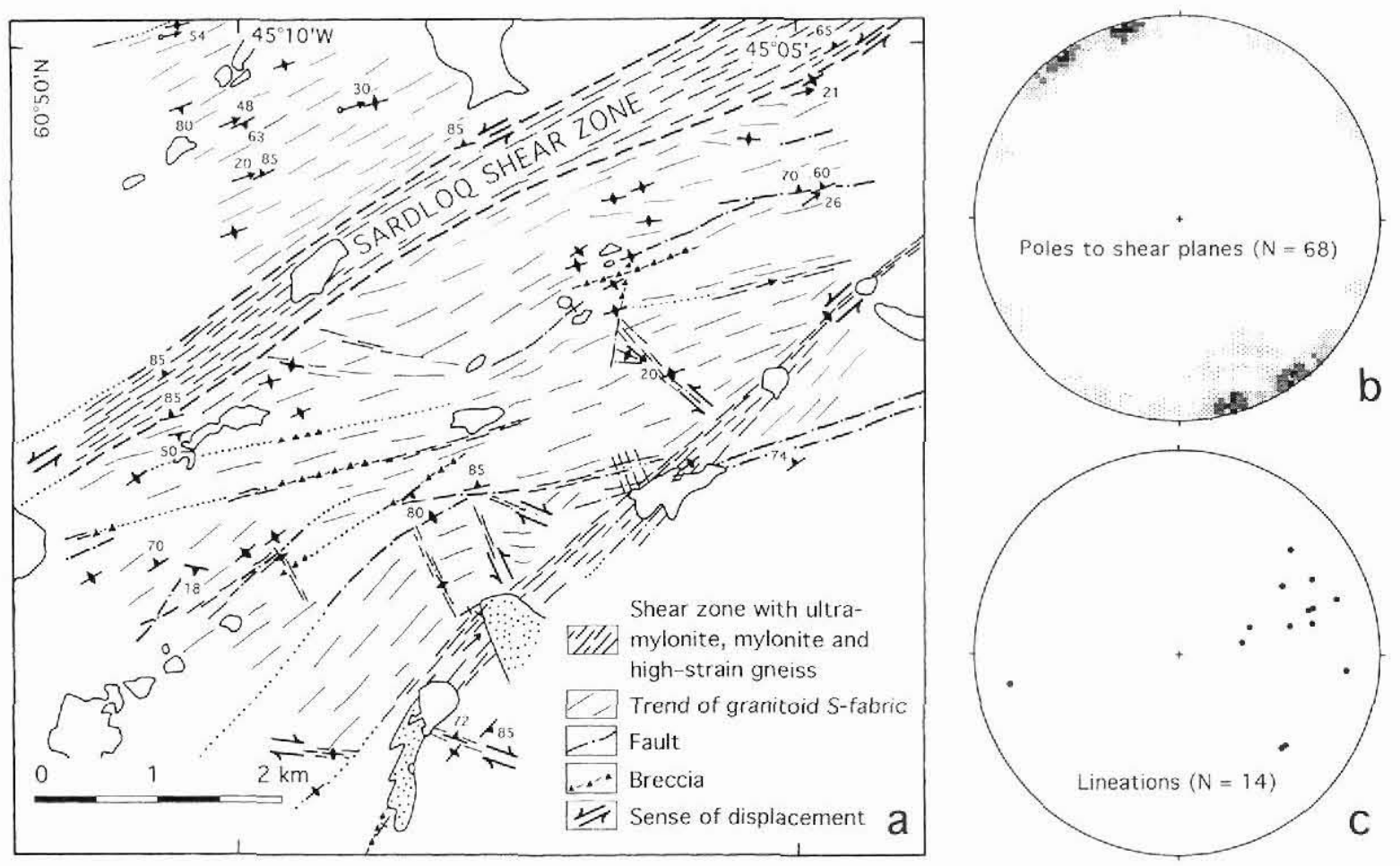

Fig. 7. (a) Second-order shear zones, faults and breccia zones adjacent to the Sârdloq shear zone in the north-western part of the Søndre Sermilik area (location shown on Fig. 2). The sinistral transcurrent shear zones trend NE and rarely SE, whereas conjugate dextral shear zones trend E to ESE. The narrow NE-trending breccia zones are all Jocaled within previously developed shear zones. (b) Distribution of poles to shear planes measured in the field within the area shown on Fig. 7a (equal area density plot, lower hemisphere, 5 classes at $4.5 \%$ intervals). The planes are steep to vertical, with two strike maxima at $55^{\circ}$ and $75^{\circ}$ which correspond to the sinistral shear zones. The smaller clusters at $95^{\circ}$ and $115^{\circ}$ correspond to dextral shear zones.

(c) Wulff plot of linear structures (mineral and stretching lineations as well as long axes of deformed inclusions) from the area of Fig. 7a. The mean lineation vector for 12 of the 14 measurements plunges $22^{\circ}$ in the direction $070^{\circ}$, approximately parallel to the inferred movement along the Sârdloq shear zone.

appear to be the result of partial melting that was contemporaneous with the development of the high-strain gneisses. The belt of high-strain gneiss appears to have been contemporaneous with the regional shear zones trending NE-SW. The partial melting in the belt may have been the result of localised shear heating like that proposed by Brun \& Cobbold (1980). The field relationships show that the gneisses are not relics of a gneiss complex older than the Julianchåb batholith as indicated on earlier maps. Other belts of high strain gneisses occur within the area north-west of Søndre Sermilik, but their relationships with the regional grey granodiorites were not mapped in detail. Some shear zones north-west of Søndre Sermilik were later reactivated as brittle faults in the Gardar period (Nyegaard \& Armour-Brown, 1986).

\section{Amphibolite and diorite dykes}

Amphibolitic and mafic dioritic dykes are common in the granodiorites and related rocks of the Julianehåb batholith north-west of Søndre Sermilik (Fig. 4). The dykes share many aspects in common with those described by previous workers from further north in the Julianehåb batholith (Berrangé, 1966; Allaart, 1967; Ayrton \& Burri, 1967; Walton, 1965; Watterson, 1965, 1968; Windley, 1965). We regard the dykes as members of the appinite suite in the sense of Pitcher (1993), i.e an association of basic rocks with granite that are characterised by "... the dominance of homblende and a range of modal and textural diversity." Pitcher showed that the suite may range from ultrabasic compositions through diorites to granodiorite.

Mafic hornblende-bearing dykes are found sporadically in the ground north-west of Henrik Lundip Qoorua, and they occur as a major swarm between this valley and 
Søndre Sermilik as well as in the cliffs east of Søndre Sermilik. Hornblende dioritic dykes and others with pure hornblendite composition were noted in a few outcrops, but most of the dykes were recorded as undifferentiated amphibolites. Most are fine- to medium-grained, but some include coarse hornblende textures which appear to have been the result of high water activity at the time of dyke emplacement. Some of the dykes are net-veined. The dykes are mostly $1-10 \mathrm{~m}$ wide, are steeply dipping or vertical and have widely variable trends. The dykes cut across the regional schistosity in the host granitoid rocks. but many have an internal schistosity oblique to that in their host. Along the margins of some dykes we have observed elongate, decimetre-sized dyke rafts incorporated into the host granite (Fig. 6c). Dykes in the swarm between Henrik Lundip Qoorua and Søndre Sermilik commonly curve into shear zones with NE-SW trends or they may be displaced by a few metres. The curvature of the dykes is compatible with the sense of sinistral trans-

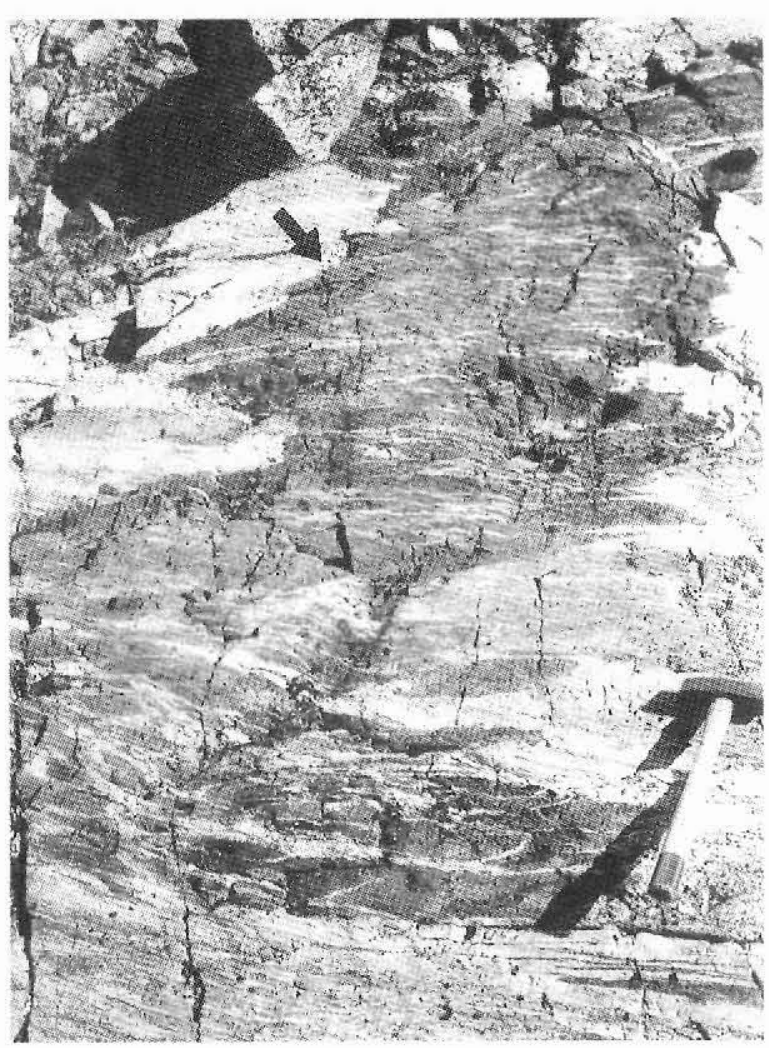

Fig. 8. Fine-grained dioritic dyke emplaced into the Sârdloq shear zone near its north-eastern end adjacent to the Inland Ice $\left(60^{\circ} 54^{\prime} \mathrm{N}, 44^{\circ} 55^{\prime} \mathrm{W}\right)$. Part of the dyke (arrow, middle distance) has almost straight margins which cut the previously sheared host rocks. whereas in the foreground the dyke itself is cut into numerous slices during subsequent shearing. current displacement in the zones. This consistent curvature and the commonly unbroken passage of dykes along the shear zones until they link with the principal parts of the dykes outside the zones indicate that their emplacement was contemporaneous with the localised plastic yielding that gave rise to the shear zones. An example of such a dyke emplaced into an active shear zone is shown in Fig. 8. At the time of emplacement of the dykes the bulk of the host rock appears to have been failing in a largely brittle condition to provide the fractures for the passage of the dyke magmas, but it was yiclding plastically in the shear zones.

The similarity in composition between many of the dykes, the large diorite bodies and the numerous small enclaves of homblende diorite and gabbroic rocks in the grey granodiorites suggests that they were consanguineous. Figure 9 shows an example of the relationships between the host granodiorite. gabbroic rocks and amphibolite dykes with several directions (mainly around $10^{\circ}$ and $60^{\circ}$ ) in the southern part of Niaqornarsuk peninsula.

\section{Ultramafic plugs}

Two small layered ultramafic plugs occur on the coasts of Søndre Sermilik. A hornblende peridotite $5 \mathrm{~km}$ south of the valley Ippatit has been described by Schönwandt (1972). A second body of layered, hornblende-bearing, mafic to ultramafic rocks measuring $c$. 200 by $300 \mathrm{~m}$ was located in 1993 on the north-western coast opposite to that described by Schönwandt (1972). It is possible that the ultramafic plugs are part of the appinite suite described above.

\section{Relative age of the supracrustal rocks and the Julianehåb batholith}

At this stage in our reappraisal of the Ketilidian orogen we regard the supracrustal rocks as younger than the bulk of the rocks in the Julianehab batholith, but much of the field evidence is ambiguous. Our view is based in the first instance on the fact that granitoid clasts are common in the conglomerates. Secondly, contacts at the head of Danell Fjord on the east coast (Nielsen et al., 1993) show that whereas some plutonic complexes of the batholith intrude the overlying supracrustal rocks, others may have formed their basement and the provenance of their metasedimentary components. Boundary relationships between the granodiorites of the batholith and overlying supracrustal rocks high above the valley of Ippatit south of Søndre Sermilik suggest comparable age relationships (Nielsen et al., 1993), although sheared contacts seen from the air may be the result of thrusting. The greater abundance of amphibolite dykes in the Julianehab batho- 

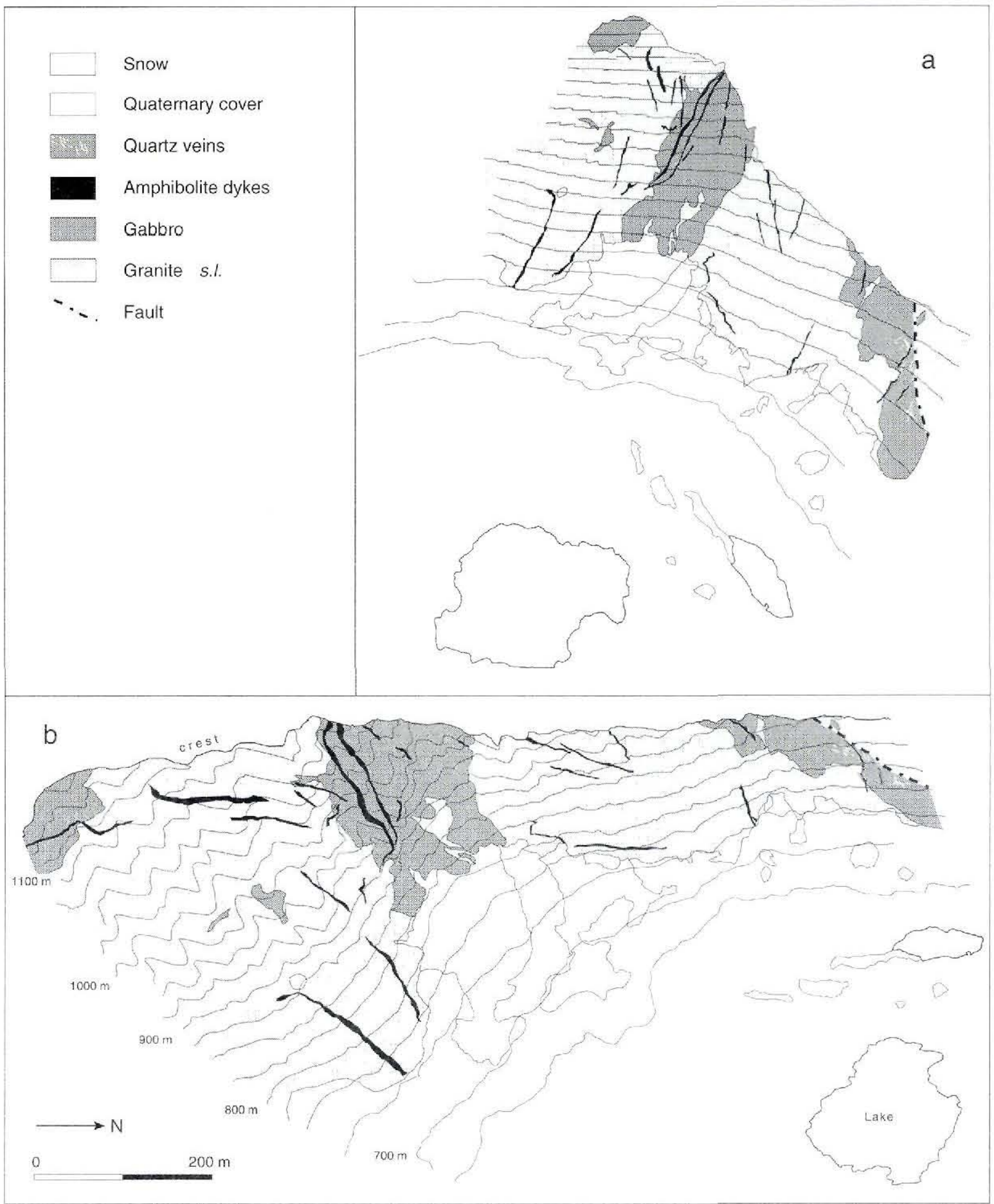

Fig. 9. (a) Perspective (direction of view $190^{\circ}$ at $70^{\circ}$ from vertical) and (b) geological map of a small area in the southern part of the valley Qoorormiut on Niagornarsuk peninsula (location see arrow in Fig. 2). Numerous thin amphibolite dykes with two prominent directions around $10^{\circ}$ and $60^{\circ}$ cut granodiorite and syngenetic gabbroic bodies. The northernmost gabbroic body is affected by a shear zone and fault trending c. $20^{\circ}$ and hosts several shear-related, up to $1 \mathrm{~m}$ thick gold-bearing quartz veins. The figure was prepared from $24 \times 36 \mathrm{~mm}$ colour slides taken from a helicopter, using multi-model photogrammetry at the Technical University of Denmark (see Dueholm, 1992 and Ducholm et al., 1993 for description of the method). 
lith compared with the supracrustal rocks suggests that the batholith may be older, although syn- and late-tectonic amphibolite dykes are relatively common in flatlying psammites on the east coast. Finally, xenoliths of supracrustal rocks are extremely uncommon in the batholith, although certain large bodies of pale quartzo-feldspathic rocks in the eastern part of the valley Niaqornarsuk appear to be supracrustal xenoliths. Many of these rocks are fine-grained, but in some outcrops they contain numerous granitoid clasts. It is conceivable that the finegrained rocks are acid pyroclastic rocks which may be remnants of a collapsed caldera system near the roof of the batholith.

\section{Plutonic setting of the Julianehåb batholith}

The widespread occurrence of the penetrative schistosity and linear fabric (preferred orientation of minerals and long axes of deformed enclaves), including $L$ tectonites, in the rocks of the batholith north-west of Søndre Sermilik suggests that these fabrics formed during late stages of emplacement, not as the result of later superimposed deformation. However, we have no thin section data to indicate the extent to which these fabrics were pre-full (igneous) crystallisation or crystal plastic in the sense of Hutton (1988). On the grounds of the broad parallelism between the regional $\mathrm{L}$ fabric and that in the NE-trending, sinistral shear zones, and the fact that the regional schistosity is intensified adjacent to the zones, it can be argued that the localised plastic yielding that gave rise to the shear zones and belts of high-strain gneisses also occurred as part of the development of the batholith. Different parts of the batholith were failing at different times in a brittle condition during the ductile periods of deformation to facilitate the injection of the synplutonic mafic dykes. Because of these relationships we conclude that the Julianehåb batholith was emplaced in a regime of sinistral transpression. We use the term transpression in the general sense of Sanderson \& Marchini (1984), i.e. to include the more specific transpression and transtension of Harland (1971). We regard the sinistral transpression as an effect of oblique plate collision as new early Proterozoic crust was accreted onto the Archaean craton of South Greenland in accord with the isotopic age data reviewed by Kalsbeek et al. (1990).

Our interpretation of the emplacement of the Julianehåb batholith during sinistral transpression is in accord with the view of Bridgwater et al. (1973) that transcurrent displacements were locally important, although they concluded that "the dominant movements, at least in the younger stages of the history of the (Ketilidian) mobile belt, have been a mixture of vertical movements associated with the rise of large quantities of igneous material and horizontal movements parallel to the border of the belt resulting in the formation of transcurrent shear belts."

Our view that emplacement of the Julianehåb batholith took place during sinistral transpression contrasts with the interpretation of the Ketilidian orogen belt in terms of the Himalayan plate collision model proposed by Windley (1991). Drawing heavily on the summary of the geology of the Ketilidian belt by Allaart (1976), Windley argued that the belt could be subdivided into five principal zones comparable in type and spatial distribution with those in the Himalayas and the contiguous Karakoram region, which forms the uplifted western end of the Tibetan plateau. Windley (1991) adopted the view of Bridgwater et al. (1973) that the Julianehåb batholith compares closely with the Andean batholiths. He proposed that the batholith was intruded into an Andean-type continental margin and may have incorporated a mature island arc of volcanic and plutonic rocks that had already accreted onto the margin. He based this proposal on the alleged "many inclusions [in the early granites of the batholith] of basic, acid, and intermediate metavolcanic rocks ranging from amphibolites and hornblende schists to recognisable lava flows and pyroclastic deposits, some of which were certainly deformed before incorporation into the granitic rocks." Inclusions which were believed by previous workers to have been supracrustal rocks (for example, the large bodies of amphibolite and sheets of aplite mapped as such by Persoz, 1969) are in fact of plutonic origin and part of the batholith itself. The existence of a pre-existing mature arc based on the composition of inclusions in the batholith is thus open to question. Windley $(1991$, p. 4) also interpreted the southern part of the Julianehåb batholith "... as a ductile shear zone in a back-arc position" on the grounds of the presence of "rafts of basic metavolcanic rocks (Allaart, 1976)", and he thought that the structure was the result of direct collision without significant lateral slip.

Our survey in 1993 has shown that these 'rafts' are intrusive bodies of hornblende diorite that are integral parts of the batholith, and we found no evidence of a back-arc in this area as proposed by Windley. Furthermore, the major shear zones in this part of the batholith were the effect of essentially sinistral transcurrent displacements.

\section{Hydrothermal activity and gold mineralisation associated with sinistral transpression}

The emplacement of the southern part of the Julianehåb batholith in a sinistral transpressional tectonic regime was accompanied not only by the generation of penetrative regional $\mathrm{S}$ and $\mathrm{L}$ fabrics and localised intense 


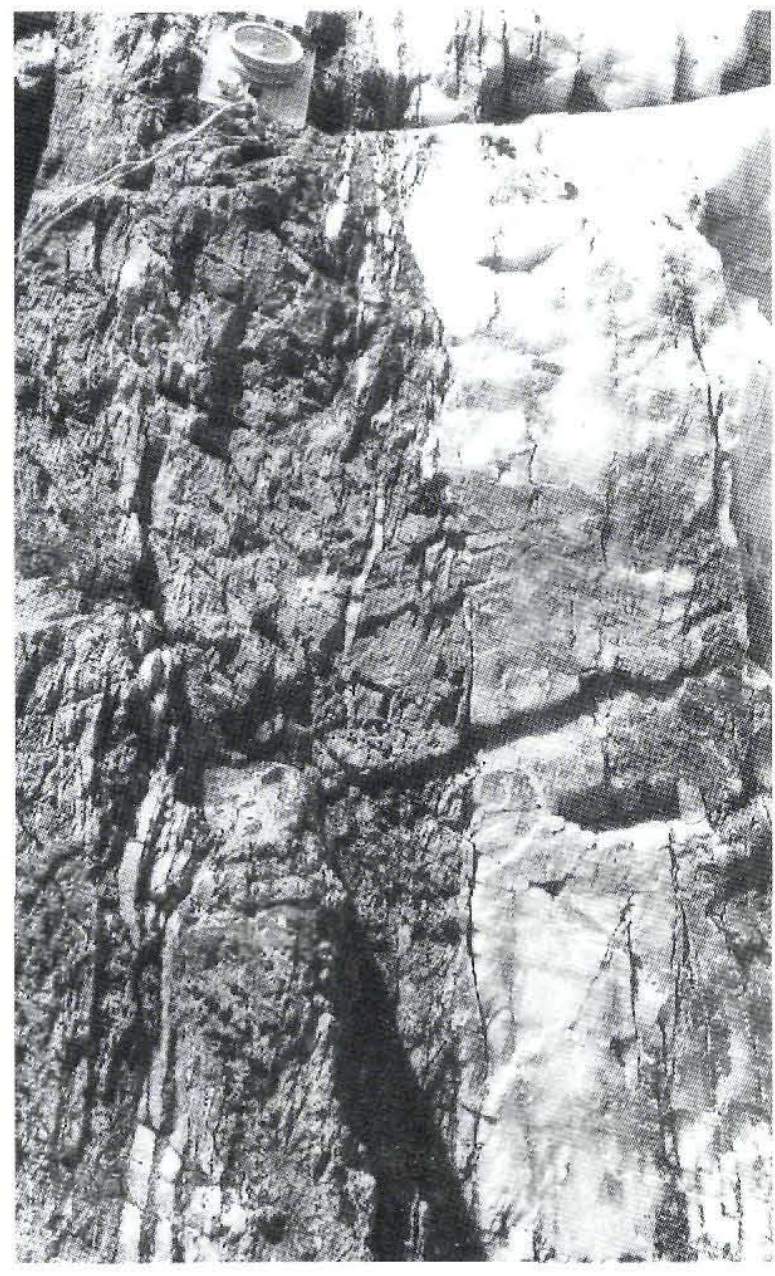

Fig. 10. Quartz vein system parallel to mylonitic rocks in the central part of an E-W trending shear zone above the head of Søndre Sermilik. The thickest mylonite-hosted quartz veins are up to $30 \mathrm{~m}$ long and about $30-40 \mathrm{~cm}$ thick.

plastic yielding in the shear zones and belts of high strain gneisses as described above, but also by significant quartz veining, brecciation and hydrothermal alteration. These effects took place in P-T conditions of middle amphibolite to low greenschist facies and in various rheological settings. A preliminary interpretation of gold analyses of rock samples collected in 1993 (see below) suggests that the late stages of batholith emplacemem were also accompanied by gold mineralisation.

As already mentioned several gold anomalies were known from stream sediment surveys and local chip sampling programmes in the area prior to the present investigation. In order to evaluate the source and nature of these anomalies a regional sampling programme was carried out. A total of 297 chip and rock samples from the area north-west of Søndre Sermilik were collected and subsequently analysed for gold. The major part of the samples was collected in or adjacent to high-strain and mylonite zones in the batholith. They fall into three groups: (1) quartz veins and silicified rocks, (2) breccias, and (3) hydrothermally altered rocks. The analytical results are presented in Table 1 and Fig. 11. Gold contents above $100 \mathrm{ppb}$ (equivalent to the $971 / 2$ percentile), which we consider anomalous, were found in all three groups of samples (see below), and the highest gold values seem to be concentrated along the NNE-trending shear zone system in the eastern part of the Niagornarsuk peninsula. A couple of other samples not related to the shear zones also yielded interesting gold values (around $100 \mathrm{ppb}$ ), but will not be discussed further here.

\section{Quartz veins}

Quartz veins occur widely in the Julianehåb batholith and in the local enclaves of supracrustal rocks north-west of Søndre Sermilik. Most of the veins have steep dips and widely variable strike. Quartz veins in the granitoid rocks of the batholith are c. $1-30 \mathrm{~cm}$ thick, are commonly traceable for 10-100 $\mathrm{m}$ and most are deformed. The vein

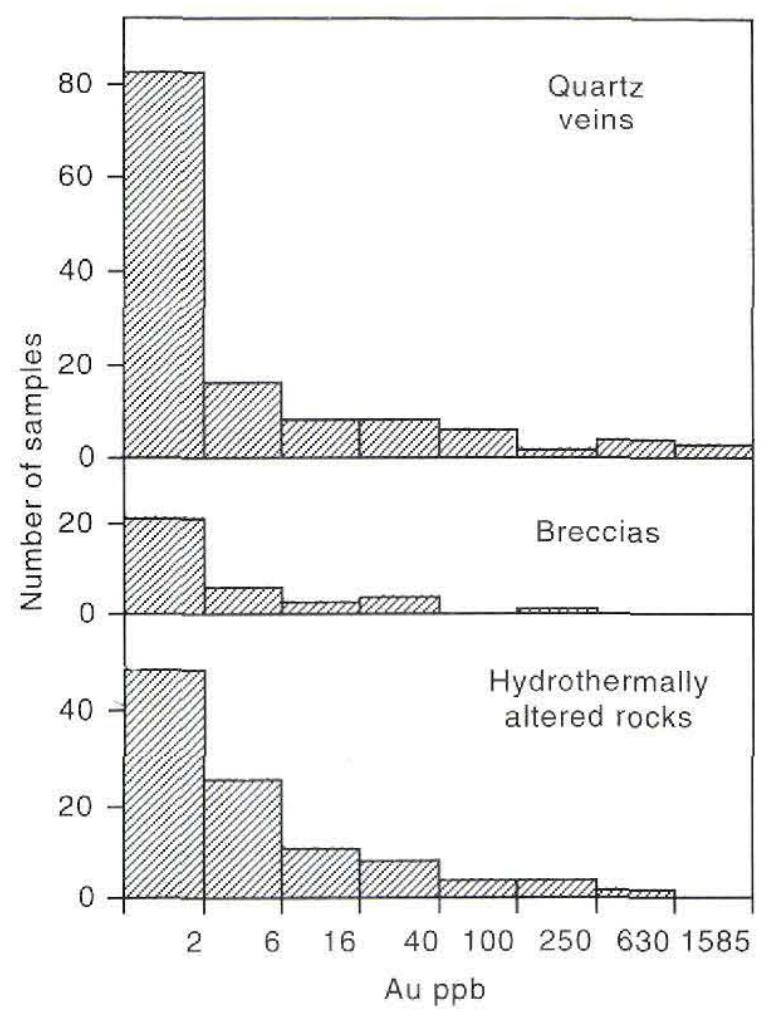

Fig. 11. Distribution of gold in rock and chip samples from three groups of rocks in or adjacent to shear zones in the Sondre Sermilik area. 
Table 1. Summary statistics for gold in rock samples in the Søndre Sermilik area

\begin{tabular}{lrrr}
\hline & Quartz veins & Breccias & $\begin{array}{c}\text { Hydrothermally } \\
\text { altered rocks }\end{array}$ \\
\hline $\begin{array}{l}\text { No of samples } \\
\text { No of samples } \\
\quad 100 \mathrm{ppb}\end{array}$ & 128 & 35 & 104 \\
$\begin{array}{l}\text { Range } \\
\text { Median }\end{array}$ & $<-1000$ & $<-120$ & $62-432$ \\
Average & $<2$ & $<2$ & $<3$ \\
\hline
\end{tabular}

All values in $\mathrm{ppb}$.

Analysis: instrumental neutron activation, ACTLABS, Canada.

quartz may be either vitreous or 'milky' and usually barren of ore minerals, although disseminated pyrite may occur locally.

The quartz veins are most abundant in the quartzofeldspathic supracrustal rocks in the vicinity of Niaqornarsuk valley. In one part they make up $20-30 \%$ of the total volume in an area measuring 20 by $100 \mathrm{~m}$. The veins may be up to $1 \mathrm{~m}$ thick, they are sheared, and contain minor amounts of pyrite.

Quartz veins are commonly associated with mylonites and ultramylonites in shear zones and range from a few millimetres to $40 \mathrm{~cm}$ in thickness. They are up to $30 \mathrm{~m}$ long and are commonly concentrated in zones about a metre wide in which the veins may constitute $c .50 \%$ of the total volume (Fig. 10). Quartz veins in the mylonites may contain epidote and chlorite, but pyrite is generally present in only very minor amounts. Wall rocks are commonly impregnated with fine-grained quartz. The veins, which are parallel to the mylonite fabric, are commonly very fine-grained with a flinty aspect and fine-scale lamination, indicating that the veins were deformed during the mylonitisation. Some of the veins which are not parallel to the mylonite fabric appear to have filled tensile fractures that were contemporaneous with shear zone formation, whereas others appear to be younger. The latter have vitreous quartz and may be full of micro-joints perpendicular to vein boundaries. Figure 9 illustrates the setting of gold-bearing quartz veins adjacent to a small shear zone in a mafic body within the Julianehåb batholith.

Many of the synplutonic amphibolite dykes, especially the sheared dykes, include quartz veins as tensile fracture fillings. These veins are up to $1 \mathrm{~m}$ thick, but normally less than $10 \mathrm{~m}$ long. Quartz in these veins is white and massive. Thinner quartz veins also commonly occur along one or both margins of the synplutonic dykes. An exceptional vein about $1 \mathrm{~m}$ thick and traceable for at least $100 \mathrm{~m}$ was found along the margin of an amphibolite dyke in the valley of Niaqornarsuk. The vein branches away from the dyke boundary and extends into the host granodiorite and supracrustal quartzo-feldspathic rocks. Trace amounts of pyrite and occasionally base metal sulphides occur within the quartz veins associated with the amphibolite dykes, and greater concentrations of pyrite are found in the margins of some of the sheared dykes. Chalcopyrite may accompany pyrite in the veins and dyke rock, although it is also found in the host granitoid rocks adjacent to the dykes.

Analyses of quartz veins and adjacent silicified rocks from shear zones show the highest average ( $37 \mathrm{ppb}$ ) and maximum (1000 ppb) gold content of the three sample groups (Table 1, Fig. 11). However, the gold content of most samples is below the detection limit of $2 \mathrm{ppb}$.

\section{Breccias}

Narrow zones of breccia and coarsely fractured cataclastites occur locally within the major belts of Ketilidian mylonite and in other younger fracture zones. The breccias are cut by Gardar dykes and most of them are presumed to be effects of brittle deformation very late in the Ketilidian sinistral transpression. Most of the breccias appear to be concentrated in a 1-2 km wide belt along the south-eastern margin of the Sârdloq shear zone (Fig. 7a). Early stages of brecciation appear to be represented by the distortion and fracturing of parts of the mylonitised granitic rocks. Voids formed by this distortion are filled by quartz with local minor pyrite. Other breccias older than the Gardar dykes include abundant hematite and chlorite with the matrix quartz.

Post-Ketilidian E-W fractures which commonly give rise to persistent topographic lineaments have been described by Nyegaard \& Armour-Brown (1986). They include locally abundant, coarsely fractured cataclasites, although displacements on the fractures appear to be insignificant in the areas we have surveyed.

Gold values obtained from breccia samples are lower than in the two other analysed groups, with an average of less than $10 \mathrm{ppb}$ and only one out of 35 samples above $100 \mathrm{ppb}$ (Table 1, Fig. 11).

\section{Hydrothermal alteration zones}

Localised hydrothermal alteration in the area adjacent to Søndre Sermilik occurred both during and after the emplacement of the Julianehåb batholith and was mostly coupled with the development of shear zones, intrusion of mafic dykes and aplites, and quartz veining and brecciation as described in previous sections. These alteration zones are commonly less than $1 \mathrm{~m}$ wide, but some are $5-10$ or even up to $100 \mathrm{~m}$ wide. Another type of hydrothermal alteration occurs sporadically in low-strain areas 
within the batholith and is visible as rusty, few metres long zones with numerous sulphide-bearing 'hairline' fractures and veinlets. The hydrothermal alteration gave rise to silicification, feldspathisation, chloritisation, epidotisation and pyritisation. New phases are quartz, plagioclase (albite?), alkali feldspar, epidote, chlorite, carbonates (calcite, dolomite, siderite, ankerite), pyrite, pyrrhotite, magnetite and hematite. Copper sulphides, galena and sphalerite have also been found. Post-Ketilidian britthe fracture zones are commonly marked by reddening of feldspar but rarely contain other signs of hydrothermal activity.

The most intense hydrothermal alteration observed occurs in a north-east-trending vertical brittle-ductile fault situated $c .2 \mathrm{~km}$ south of the Sârdloq shear zone: the fault appears to be a second-order structure related to the shear zone. The zone of alteration is at least $300 \mathrm{~m}$ long and 6-15 $\mathrm{m}$ wide, and it affects both the regional granodiorite and an amphibolite dyke older than the lineament. The alteration and deformation increase towards the centre where the original rocks can no longer be recognised. Here a 3-8 $\mathrm{m}$ wide zone of intense carbonatisation, silicification and chloritisation occurs, which appears to have been subsequently affected by brecciation and development of vugs partly filled by quartz. The final result is a quartz-carbonate-chlorite breccia accompanied by a zone of intense silicification up to $1 \mathrm{~m}$ wide. The alteration zone is mineralised with a few per cent of pyrite, which varies from fine-grained disseminations to euhedral crystals $c .1 \mathrm{~mm}$ in size. In addition, up to $c .5 \%$ fineto coarse-grained galena and chalcopyrite were found over a strike length of $65 \mathrm{~m}$, both in the breccia and the silicified rock. The sulphides occur disseminated and as veinlets up to $8 \mathrm{~cm}$ long. The iron and copper sulphides are variably altered to iron oxide and copper carbonates. Manganese oxide and platy barite were noted on fracture surfaces.

Hydrothermally altered rocks occupy an intermediate position with respect to gold mineralisation when compared with the two other sample groups (Table 1 and Fig. 11).

\section{Conclusions}

Recent field work in the central part of the Early Proterozoic Ketilidian orogen, which was previously believed to comprise the Julianehåb granite, highly metamorphosed supracrustal rocks and older orthogneisses, has shown that this part of the orogen consists of an I-type granite batholith. Steeply dipping, NE-SW trending shear zones with sinistral displacement are a significant element of the regional structure and formed under amphibolite and greenschist facies conditions. Syntec- tonic mafic dykes of the appinite suite were intruded during the evolution of the batholith, especially in its southern part. We propose that the Julianehåb batholith was emplaced during subduction from the south towards the Archaean craton in the north in a sinistral transpressional system.

Effects of hydrothermal activity, mainly in the form of quartz veining and silicification, are widespread and especially common in and adjacent to the shear zones. Quartz veining has taken place throughout the development of the shear zones, but some of the veins also postdate them. Most of the hydrothermal activity was related to the late stages of the evolution of the batholith.

A close link between gold mineralisation and shear zones, especially in the southernmost part of the batholith on the Niaqornarsuk peninsula, is indicated by the distribution of gold anomalies. Regional chip and grab samples in the structural lineament zones gave a wide range of gold values in a skewed distribution with up to 1000 ppb Au and 14 samples in excess of 100 ppb.

\section{References}

Allaart, J. H. 1967: Basic and intermediate igneous activity and its relationship to the evolution of the Julianehåb granite, South Greenland. Bull. Gronlands geol. Unders. 69, 136 pp. (also Meddr Grønland 175,1).

Allaart, J. H. 1975: Geological map of Greenland 1:500 000 sheet 1, Sydgrønland. Copenhagen: Grønlands Geologiske Undersøgelse.

Allaart, J. H. 1976: Ketilidian mobile belt in South Greenland. In Escher, A. \& Watt, W. S. (ed.) Geology of Greenland, 121-151. Copenhagen: Grønlands Geologiske Undersøgelse. Andrews, J. R., Bridgwater, D., Gulson, B. \& Watterson, J. 1971: Reconnaissance mapping of South-East Greenland between $62^{\circ} 30^{\prime} \mathrm{N}$ and $60^{\circ} 30^{\prime} \mathrm{N}$. Rapp. Gronlands geol. Unders. 35, 32-38.

Andrews, J. R., Bridgwater, D., Gormsen, K., Gulson, B., Keto, L. \& Watterson, J. 1973: The Precambrian of South-East Greenland. In Park, R. G. \& Tarney, J. (ed.) The Lewisian of Scotland and related rocks of Greenland, 143-156. Birming. ham U. P.

Appel, P. W. U., Lind, M. \& Nielsen, J. P. 1993: Gold exploration on the 'Nanortalik peninsula', South Greenland. Open File Ser. Gronlands geol. Unders. 93/3, 66 pp.

Armour-Brown, A. 1986: Geology and evaluation of the uranium mineral occurrence at Igdlorssuit. South Greenland. The South Greenland Exploration Programme 1984-1986. Report No. 2. Open File Ser. Grønlands geol. Unders. 86/2, $60 \mathrm{pp}$.

Armour-Brown, A., Steenfelt, A. \& Kunzendorf, H. 1983: Uranium districts defined by reconnaissance geochemistry in South Greenland. J. geochem. Explor. 19, 127-145.

Armour-Brown, A., Tukiainen, T. \& Wallin, B. 1982: The South Greenland uranium exploration programme. Final report. Unpubl. intern. GGU rep., 95 pp. 
Ayrton, S. \& Weidmann, M. 1963: Report on field work by S. Ayrton and M. Weidmann, during the summer Campaign of 1963. Unpubl. intern. GGU rep.

Ayrton, S. N. \& Burri, M. 1967: L'évolution du socle précambrien dans le région de Qagssimiut, Groënland méridional. Bull. Grønlands geol. Unders. 66, 90 pp. (also Meddr Grønland 175,2).

Ball, S. H. 1923: The mineral resources of Greenland. Meddr Grønland 63(1), $60 \mathrm{pp}$.

Berrangé, J. P. 1966: The bedrock geology of Vatnahverfi, Julianehåb district, South Greenland. Rapp. Grønlands geol. Unders. 3, 48 pp.

Berrangé, J. P. 1970: The geology of two small layered hornblende peridotite (picrite) plutons in South Greenland. Bull. Gronlands geol. Unders. 92, 43 pp.

Bondam, J. 1992: Graphite occurrences in Greenland. Open File Ser. Grønlands geol. Unders. 92/6, $32 \mathrm{pp.}$

Bridgwater, D. \& Gormsen, K. 1969: Geological reconnaissance of the Precambrian rocks of South-East Greenland. Rapp. Grønlands geol. Unders. 19, 43-50.

Bridgwater, D., Escher, A. \& Watterson, J. 1973: Tectonic displacements and thermal activity in two contrasting Proterozoic mobile belts from Greenland. Phil. Trans. roy. Soc. Lond., A, 273, 513-533.

Bridgwater, D., Sutton, J. \& Watterson, J. 1966: The Precambrian rapakivi suite and surrounding gneisses of the Kap Farvel area, South Greenland. Rapp. Grønlands geol. Unders. 11, 52-54.

Brun, J. P. \& Cobbold, P. R. 1980: Strain heating and thermal softening in continental shear zones: a review. J. struct. Geol. 2, 149-158.

Buttet, P. 1963: Géologie de la region de Qagdlumiut. Rapport préliminaire. Unpubl. intern. GGU rep., $12 \mathrm{pp}$.

Dawes, P. R. 1970: The plutonic history of the Tasiussaq area, South Greenland, with special reference to a high-grade gneiss complex. Bull. Grønlands geol. Unders. 88, 125 pp. (also Meddr Grønland 189,3).

Dawes, P. R. \& Schønwandt, H. K. 1992: Geological setting of Precambrian supracrustal belts: a fundamental part of mineral resource evaluation in Greenland. Rapp. Gronlands geol. Unders. 155, 19-23.

Dennis, A. J. \& Secor, D. T. 1987: A model for the development of crenulations in shear zones with applications from the Southern Appalachian Piedmont. J. struct. Geol. 9, 809-818.

Dueholm, K. S. 1992: Geologic photogrammetry using standard small-frame cameras. Rapp. Gronlands geol. Unders. 156, 7-17.

Dueholm, K. S., Garde, A. A. \& Pedersen, A. K. 1993: Preparation of accurate geological and structural maps, crosssections or block diagrams from colour slides, using multimodel photogrammetry. J. struct. Geol. 15, 933-937.

Escher, A. 1966: The deformation and granitisation of Ketilidian rocks in the Nanortalik area, S. Greenland. Bull. Gronlands geol. Unders. 59, 102 pp. (also Meddr Gronland 172,9).

Garde, A. A. \& Schønwandt, H. K. 1994: Project SupRAsYD1993 - field work in the central part of the Julianehăb batholith, South Greenland. Rapp. Gronlands geol. Unders. 160, 27-31.
Gowen, J., Christiansen, O., Grahl-Madsen, L., Pedersen, J., Petersen, J. S. \& Robyn, T. L. 1993: Discovery of the Nalunaq gold deposit, Kirkespirdalen, SW Greenland. Int. Geology Review 35, 1001-1008.

Harland, W. B., 1971: Tectonic transpression in Caledonian Spitsbergen. Geol. Mag. 108, 27-42.

Hutton, D. H. W., 1988: Granite emplacement mechanisms and tectonic controls: inferences from deformation studies. Trans. roy. Soc. Edinb.: Earth Sci. 79, 245-255.

Kalsbeek, F., Larsen, L. M. \& Bondam, J. 1990: Geological map of Greenland 1:500 000: Sydgrønland Sheet 1. Descriptive text, 36 pp. Copenhagen: Grønlands Geologiske Unders $\varnothing$ gelse.

Karup-Møller, S. 1974: Report on the 1973 survey of the Nanortalik concession. Int. rep., The Greenland Mineral Exploration Syndicate, $47 \mathrm{pp}$.

Lister, G. S. \& Snoke, A. W. 1984: S-C mylonites. J. struct. Geol. 6, 617-638.

Muller, J. 1961: Analyse structurale dans quelques granites de la presqu'ile située entre les fjords d'Unartok et de Sermilik. Unpubl. intern. GGU rep.

Nielsen, L. M. 1987: Rapport over geologiske unders $ø$ gelser i Nanortalik kommune i 1986. Intern. rep., Nanortalik kommune, 17 pp.

Nielsen, T. F. D., Chadwick, B., Dawes, P. R., Frith, R. A. \& Schønwandt, H. K. 1993: Project Suprasyd 1992: opening season in the Ketilidian of South Greenland. Rapp. Gronlands geol. Unders. 159, 25-31.

Nyegaard, P. \& Armour-Brown, A. 1986: Uranium occurrences in the granite zone. Structural setting - genesis - exploration methods. South Greenland Exploration Programme 1984 1986, Report No. 1. Open File Ser. Gronlands geol. Unders. 86/1, $138 \mathrm{pp}$.

Persoz, F. 1969: Évolution plutonique et structurale de la presqu'île d'Akuliaruseq, Groenland méridional. Bull. Gronlands geol. Unders. 72, 202 pp. (also Meddr Grønland 175,3).

Pitcher, W. S. 1993: The nature and origin of granite, $321 \mathrm{pp}$. London: Blackie Academic and Professional.

Sanderson, D. J. \& Marchini, W. R. D. 1984: Transpression. J. struct. Geol. 6, 449-458.

Schönwandt, H. K. 1972: Geological and geophysical work on ultramafic rocks in the Nanortalik area, South Greenland. Rapp. Gronlands geol. Unders. 45, 35-36.

Steenfelt, A. 1987: Gold in the fine fraction in stream sediments from supracrustal sequences in West Greenland. Open File Ser. Grønlands geol. Unders. 87/2, 10 pp.

Steenfelt, A. 1990: Gold content of regional stream sediment samples from South Greenland. Open File Ser. Gronlands geol. Unders. 90/5, 12 pp.

Steenfelt, A. \& Armour-Brown, A. 1988: Characteristics of the South Greenland uranium province. In IAEA (ed.) Recognition of uranium provinces, 305-335. Vienna: International Atomic Energy Agency.

Steenfelt, A. \& Tukainen, T. 1991: Geochemical mapping: distribution of gold, arsenic, antimony and tantalum in South Greenland. Rapp. Grønlands geol. Unders. 152, 55-61.

Turner, P. A., Bow, C., Gothenborg, J. \& Della Valle, G. 1988: Report of 1988 field season, Nanortalik and Nunarssuit con- 
cessions. Int. rep., Boulder Gold Group/Platinova Resources Ltd. Joint venture, $40 \mathrm{pp}$.

van Breemen, O., Aftalion, M. \& Allaart, J. H. 1974: Isotopic and geochronologic studies on granites from the Ketilidian Mobile Belt of South Greenland. Bull. geol. Soc. Am. 85, 403-412.

Walton, B. J. 1965: Sanerutian appinitic rocks and Gardar dykes and diatremes, north of Narssarssuaq, South Greenland. Bull. Gronlands geol. Unders. 57, 66 pp. (also Meddr Grønland 179,9).

Watterson, J. 1965: Plutonic development of the Ilordleq area, South Greenland. I: Chronology, and the occurrence and recognition of metamorphosed basic dykes. Bull. Gronlands geol. Unders. 51, 147 pp. (also Meddr Grфnland 172,7).

Watterson, J. 1968: Plutonic development of the Ilordleq area, South Greenland. II. Late-kinematic basic dykes. Bull. Gronlands geol. Unders. 70, 104 pp. (also Meddr Grønland 185,3).
White, S. H., Burrows, S. E., Carreras, J., Shaw, N. D. \& Humphreys, F. J. 1980: On mylonites in ductile shear zones. J. struct. Geol. 2, 175-187.

Windley, B. F. 1965: The composite net-veined diorite intrusives of the Julianehåb district, South Greenland. Bull. Grønlands geol. Unders. 58, 60 pp. (also Meddr Gronland).

Windley, B. F. 1966a: The Precambrian geology of the Sârdloq area, South Greenland. Rapp. Grønlands geol. Unders. 5, $48 \mathrm{pp}$.

Windley, B. F. 1966b: Superposed deformations of the Ketilidian gneisses in the Sârdloq area, South Greenland. Bull. Grønlands geol. Unders. 64, 55 pp. (also Meddr Grønland 179,3).

Windley, B. F. 1991: Early Proterozoic collision tectonics, and rapakivi granites as intrusions in an extensional thrust-thickened crust: the Ketilidian orogen, South Greenland. Tectonophysics 195, 1-10. 